\title{
DNA Fragmentation Index
}

National Cancer Institute

\section{Source}

National Cancer Institute. DNA Fragmentation Index. NCI Thesaurus. Code C135408.

The determination of the amount of the deoxyribonucleic acid fragmentation within the nucleated cells in a biological sample. 